\title{
Locke on the Labor of Freedom
}

\author{
Douglas Casson
}

\author{
St. Olaf College
}

\begin{abstract}
John Locke's epistemological writings are best understood as regulative or performative rather than explanatory. Locke does not simply want to describe the workings of the mind; he wants to reform the way his readers think and act. This task is crucial because it is through intellectual labor that human beings constitute themselves as genuine free agents. To this end Locke presents two accounts of freedom in the Essay. The first account stems from Hobbes and is limited to a type of self-expression through action. The second account is distinct from Hobbes's notion and requires a type of self-transcendence through judgment. Although he never rejects the first account, he implies that it is only by conforming to the second account that individuals can become truly free and reasonable selves capable of self-government.
\end{abstract}

John Locke's purpose in writing the Essay Concerning Human Understanding was not simply to explore epistemological difficulties or even to describe the intricate machinery of our minds. He wanted to reform the way his readers think and act. By turning their attention to the habits of their understanding, he set out to change their intellectual conduct, to transform the way they governed themselves. Locke was at pains to convince his readers that they must discipline both their intellect and their will if they wish to respond appropriately to the controversies that surround them.

Seen in this light, Locke's epistemological writings are decidedly political. He draws this connection himself in the "Epistle to the Reader" at the beginning of the Essay. Here he tells us that the idea to write the Essay emerged out of a discussion that he had with five or six friends in his apartment at Exeter House in London. ${ }^{1}$ When their conversation turned to the controversial matters of religion and morality, the discussants,

found themselves quickly at a stand by the Difficulties that rose on every side. After we have a while puzzled our selves, without coming any nearer a Resolution of these Doubts which perplexed us, it came into my Thoughts, that we took a wrong course; and that, before we set our selves upon Enquiries of that Nature, it was necessary to examine our own Abilities, and see, what Objects our Understanding were, or were not fitted to deal with. ${ }^{2}$

Locke and his friends were perplexed by their inability to provide satisfying answers to the same religious and moral questions that were unsettling people throughout Europe. The collapse of traditional modes of justification left them wondering how they could distinguish warranted beliefs from unwarranted ones, how they could tell the dangerous fanatic from the reasonable believer. Without a publicly accessible language of justification, intellectual disputes could easily degenerate into open conflict. Quarrels over morality and religion could easily lead to political upheaval. It is in

\footnotetext{
${ }^{1}$ Locke writes only that he and his friends were "discoursing on a Subject very remote" from the subject of the Essay. However Locke's close friend, James Tyrell, recorded at the time that this discussion took place in 1671 and concerned "the principles of morality and revealed religion." See Maurice Cranston, John Locke: A Biography (London: Longman, 1957)., 140-1, John Marshall, John Locke: Resistance, Religion and Responsibility (Cambridge: Cambridge University Press, 1994)., 49. Neal Wood speculates that the five of six friends certainly included Tyrell himself, but also Locke's patron, Shaftesbury and the physicians David Thomas, John Mapletoft, and Thomas Sydenham. Neal Wood, The Politics of Locke's Philosophy: A Social Study Of "An Essay Concerning Human Understanding (Berkeley, CA: University of California Press, 1983)., 42 .

2 John Locke and P. H. Nidditch, An Essay Concerning Human Understanding (Oxford: Clarendon Press, 1979)., 7. Subsequent quotations from the Essay will be cited parenthetically by book, chapter, and paragraph number.
} 
this context of disorder and potential violence that Locke's circle of friends "found themselves quickly at a stand."

It is significant, however, that Locke does not offer a conclusive solution to the debates that circled around him. In fact, he does not even spell out the specific religious, moral, and political questions that he and his friends were discussing. Instead of constructing a demonstrative proof or a comprehensive system, he turns his attention to our intellectual practices. He rejects the disputational style of the scholastics because it reflects the arrogance and hollowness of a type of thinking that assumes an expansive, perhaps unlimited, scope of knowledge. " ${ }^{3}$ "Our Business here is not to know all things," he writes, "but those which concern our Conduct" (I.i.6). Locke offers tentative explanations of the workings of the mind only insofar as they might be conducive to recognizing right conduct. One could say that his approach is not so much explanatory as performative or regulative. It is the transformation of our intellectual practices that lies at the heart of the Locke's epistemological writings. By showing his readers how to discipline their intellectual life appropriately, he invites them to take up the arduous task of intellectual self-governance and self-mastery.

This task is crucial for Locke because it is through intellectual labor that we constitute ourselves as mature free agents. The natural freedom that we claim as human beings is not something we possess, but something we enact. We exercise this freedom not simply by expressing our will, but by transcending it and adjusting it to conform to our long-term happiness. We experience ourselves as naturally free and reasonable insofar as we are able to step away from our own process of willing and determine whether our desires our shaped by what is most important and most valuable in the world. It is through this type of cognitive self-evaluation that we hope to harmonize our volitions and our actions with the good. For Locke it is through the hard work of self-scrutiny that we attain our natural liberty. ${ }^{4}$

One of the purposes of the Essay, then, is to persuade readers to embrace the intellectual practices that will constitute them as free and reasonable selves. Here we see how Locke's explicit political project is embedded in a much larger and more extensive engagement with the psychological and cognitive conditions within which a liberal polity can flourish. It is only by disciplining our understanding that we can become free and reasonable selves. It is only as free and reasonable selves that we can sustain constitutional self-government.

\section{UNRESTRAINED AND RESTRAINED FREEDOMS}

However the claim that Lockean freedom requires intellectual self-regulation seems to conflict with Locke's explicit statements on the matter. The definition of freedom that he presents does not mention any type of intellectual self-restraint. In fact, his view of freedom seems to follow that of Hobbes. In his famous exchange with Bishop Bramhall, Hobbes stakes out an unambiguous position:

For he is free to do a thing, that may do it if he have the will to do it, and may forbear if he have the will to forbear. ${ }^{5}$

Locke furnishes us with several strikingly similar formulations throughout the Essay. At one point, for example, he writes, "Liberty 'tis plain consists in a Power to do, or not to do; to do, or forbear doing as we will" (II.xxi.56, see also II.xxi.8, 15, 21).

\footnotetext{
${ }^{3}$ Locke associates those philosophers who attempt to construct "systems" with partisanship and fanaticism (IV.iii.6).

${ }^{4}$ Locke's perplexing use of the term "natural" to describe something that is acquired through hard work and constant vigilance is not unique to him. It parallels the approach of many writers in the early modern era who employ the language of nature and artifice in ways that highlight their interconnectedness. The blurring of these terms is due, at least in part, to a pervasive view of God as the artificer of the natural world. Thus for Bacon, Vico, and Hobbes, that which is natural is not opposed to that which is artificial. In fact, much that is called natural requires not only divine but also human creativity and artifice to come into being. One of the clearest examples of the complexity and ambiguity of this relationship can be found in the beginning of Hobbes' Leviathan: "Nature (the Art whereby God hath made and governes the World) is by the Art of man, as in many other things, so in this also imitated, that it can make an Artificial Animal" Thomas Hobbes, Leviathan, trans. Richard Tuck (Cambridge: Cambridge University Press, 1991). 9.

${ }^{5}$ Thomas Hobbes, "Of Liberty and Necessity," in Hobbes and Bramhall: On Liberty and Necessity (Cambridge: Cambridge University Press, 1999)., §3, 16.
} 
Locke echoes Hobbes in defining freedom as nothing more than the absence of external restraints to the performance of the will. A free agent is someone who has the capacity to act (or refrain from acting) according to his or her volitions. Both Locke and Hobbes assert that we are free if our actions are "up to us" and our actions are "up to us" if they are determined by our will and not thwarted by external impediments. Liberty, then, is simply the ability to express ourselves through action. A free agent is one who wills and is able to act on that willing.

This type of self-expressive freedom involves a capacity to make choices, a capacity to will one thing and not another. We must have some volition to express if we are to qualify as free. For this reason we would not consider a tennis ball a free agent, Locke tells us, because "we conceive not a Tennisball to think, and consequently not to have any Volition" (II.xxi.9). The type of liberty that Locke is discussing here is a freedom of those who are able to make choices, of those who have a will.

It is important to note, however, that neither Hobbes nor Locke would say that we must always be free to choose between one action and its incompatible alternative in order to be free agents. Our freedom relates to the action or non-action that we take, not to alternative actions that we might have taken. If we are able to act (or forbear acting) according to our will - that is, if we are able to act on our choices without being impeded from acting by external obstacles - we are free. It is irrelevant whether there happen to be impediments in place that would keep us from taking alternative actions based on alternative choices that we did not make. To illustrate this, Locke explains that a man who willingly sits in a room that is locked, sits there voluntarily. He is a free agent in relation to his action even though he is not free to leave the room if he were to desire to do so. The freedom that Locke expounds here involves the relation between action and volition. If we can perform an action (or restrain from performing an action) in accordance with our will then we are said to be free. Again, freedom in this sense is simply the ability to express oneself through action without external restraint.

Locke is certainly attracted to the clarity and simplicity of this view. Throughout the multiple revisions of the Essay, he remains committed to this fundamentally Hobbesian definition of liberty. Yet he also implies that there is something more to thoroughgoing free agency than this account provides. The Hobbesian view of freedom does not seem to capture everything he wants to include within the category of liberty. There are instances in which agents act according to their will yet still seem to lack some important aspect of free agency. Compulsive longings, destructive habits, or sheer ignorance seem at times to deform the will. An agent who acts under such harmful influences seems to lack a crucial element of genuine or thoroughgoing liberty.

In his response to Hobbes, Bishop Bramhall voices this same concern. Bramhall argues that the Hobbesian notion of liberty is inadequate because it rules out instances in which an agent acts in conformity with its will yet suffers under a type of compulsion that seems inconsistent with genuine freedom. There are moments, Bramhall writes, when an individual's "will do[es] not come upon him according to his will." An individual cannot be said to possess thoroughgoing free agency when his immediate volition is, as it were, imposed upon him. "If the will have no power over itself," Bramhall writes, "the agent is no more free than a staff in a man's hand." In order to possess true or proper liberty, an agent must be determined by a will that has control over itself.

In a scathing response, Hobbes ridicules Bramhall's enigmatic formulations. These mystifying perplexities are simply the result of the bishop's inability to settle on circumscribed definitions of freedom and will. Reiterating his claim that freedom is nothing more than the ability to act (or forbear from acting) according to the will, Hobbes unequivocally denies that the source of a volition has any bearing on whether an agent is free or not. The whole notion of determining the will is unintelligible, "For the will is appetite; nor can a man more determine his will than any other appetite, that is, more than he can determine when he shall be hungry and when not. When a man is hungry, it is in his choice to eat or not eat; this is the liberty of man." ${ }^{, 7}$ For Hobbes, it is irrelevant whether the will is the result of harmful compulsions or careful deliberations. We are free regardless of what determines the will if we are able to act upon our volitions without external impediment. The only liberty that makes sense for Hobbes is unrestricted self-expression through action.

\footnotetext{
${ }^{6}$ John Bramhall, "A Defence of True Liberty," in Hobbes and Bramhall: On Liberty and Necessity, ed. V. C. Chappell (Cambridge: Cambridge University Press, 1999)., §3(d), 44.

${ }^{7}$ Hobbes, "Of Liberty and Necessity.", §1(c), 72.
} 
Locke accepts this Hobbesian account of freedom. Yet, as Gideon Yaffe notes, he seems to share Bramhall's worry that there is something missing. ${ }^{8}$ While it is true that we experience a type of freedom when we are able to act according to our will without impediment, thoroughgoing free agency seems to require another, more robust, type of freedom. What type of freedom could this be? Locke implies that true liberty requires the capacity to escape the pernicious influence of immediate volitions. An agent must be able to transcend the will and adjust it to what is most conducive to long-term happiness. Anything less than this type of self-mastery falls short of thoroughgoing free agency. Locke asks,

Is it worth the Name of Freedom to be at liberty to play the Fool, and draw Shame and Misery upon a Man's self? If to break loose from the conduct of Reason, and to want that restraint of Examination and Judgment, which keeps us from chusing or doing the worse, be Liberty, true Liberty, mad Men and Fools are the only Freemen (II.xxi.50).

Locke's point is hard to miss. True freedom - that is, freedom worth the name - requires something more than unrestrained self-expression through action. It requires the capacity to stop oneself from "chusing or doing the worse." If we are thoroughgoing free agents we are not simply determined by immediate volitions. We are able to step away from our volitions and ascertain whether they will bring about misery or happiness. If our volitions are judged to be deficient, we are somehow able to adjust them appropriately. To experience undiminished liberty, then, is to be able to accord our will with what is best for us.

Bramhall refers to this capacity to control one's volitions as "freedom of the will." Yet Locke rejects this way of speaking because it conflicts with his precise definitions of will and freedom. For Locke, it makes no sense to say that the will possesses freedom. This is because the will is not an entity within us, but rather a power or ability that we possess. ${ }^{9}$ Likewise, freedom is a power or ability and not an entity. It is absurd to say that one power has another power because powers belong to agents not other powers. Since the will is not an agent but a power of an agent, we cannot properly say that the will possesses freedom (II.xxi.16).

So Locke rejects the term "freedom of the will," yet he nonetheless accepts something like Bramhall's position. He agrees with Bramhall that thoroughgoing free agency involves more than self-expression in action. The Hobbesian view of liberty is incomplete because it does not account for the way our notions of freedom require some type of control over the process of willing itself. There is another type of freedom that involves transcending one's own immediate desires. At times Locke even equates this second kind of freedom with what is "improperly call'd Free-Will" (II.xxi.47). For Locke (as for Bramhall) thoroughgoing free agency is more than acting according to our will. It involves the ability to distance ourselves from our will in order to judge whether our volitions are, in fact, good for us.

If we wish to experience ourselves as thoroughgoing free agents, then, it is crucial to understand just how our volitions are formed and how we can go about reforming them. In the first edition of the Essay, Locke assumes that our volitions are shaped by our judgment of the greater good. We perceive the greater good and it determines our will. However, many of Locke's readers were dissatisfied with this type of determinism. It could not explain why individuals so often fail to act in ways that would enhance their happiness. It also failed to provide a mechanism by means of which individuals could transform their volitions if they are found to be inaccurate. With encouragement and criticism from William Molyneux, Locke reworked his argument. ${ }^{10}$ In his revised and final account, the will is not determined by the greatest good, but by the most proximate one. The most proximate stimulus for us is not our judgment of our future good, but the immediate pain we feel due to the presence or absence of something we desire. Locke calls this pain "uneasiness." Uneasiness is a type of dissatisfaction, an

\footnotetext{
${ }^{8}$ Gideon Yaffe, Liberty Worth the Name: Locke on Free Agency (Princeton: Princeton University Press, 2000)., 19-20. Much of the following argument - as well as much of my understanding of Lockean free agency - is indebted to Yaffe's penetrating and insightful commentary.

${ }^{9}$ Powers, as Michael Ayers points out, are placeholders in our understanding. They are necessarily presupposed by our causal explanations, yet we do not know their exact nature. Whenever one state or change causes another, we presuppose an active power in the first and a passive power in the second. Michael Ayers, Locke: Epistemology and Ontology (New York: Routledge, 1993)., I:163, II:104.

${ }^{10}$ John Locke, The Correspondence of John Locke, ed. E. S. De Beer (Oxford: Clarendon Press, 1980)., 6:1544.
} 
inarticulate ache crying out to be relieved (II.xxi.31). It is this uneasiness that in turn determines our will.

Usually the most powerful uneasiness that we feel arises from our immediate surroundings. The greatest and most pressing pains, Locke tells us, are often the most proximate. It is no surprise, then, that our volitions should often result from an uneasiness that flows from our immediate experience. This is why we will things that are often at odds with our long-term happiness. Our will is determined by the closest, most powerful uneasiness that we feel and not by a careful evaluation of absent pleasures and pains. In these instances, we are not determined by our judgment of the greater good.

Yet this is not always the case. Locke insists that the uneasiness that determines our will need not always be the uneasiness that arises from our immediate experience. The mind has "a power to suspend the execution and satisfaction of any of its desires, and ... is at liberty to consider the objects of them; examine them on all sides, and weigh them with others" (II.xxi.47). After assessing the probable consequences of various desires and the actions that might flow from them, we are able to judge which desires are most conducive to our long-term happiness. Then we can place those desires in the central, governing position of our minds. We do this by raising the appropriate uneasiness so that it will in turn determine our will. By "due, and repeated Contemplation" we can bring a temporarily absent uneasiness "nearer to our Mind, give some relish of it, and raise in us some desire" so that it will come "to determine the will" (II.xxi.45). The process of suspension and examination leads to a judgment about a future pleasure and pain. Subsequent contemplation raises an uneasiness in ourselves, and that uneasiness can in turn determine the will.

This ability - to suspend our desires, deliberate over them, and then allow our will it be adjusted appropriately - is the source of genuine, thoroughgoing liberty. The "hinge on which turns the liberty of intellectual Beings" is their capacity to "suspend their desires, and stop them from determining their wills to any action, till they have duly and fairly examin'd the good and evil of it" (II.xxi.52). As free agents, Locke teaches, we have the power to step away from our immediate desires and judge whether the our will is conducive to our long-term happiness. If our will is inconsistent with the good, we have the power to reform our volitions appropriately by raising an alternative uneasiness in our minds.

This capacity to suspend and examine our desires is a crucial aspect of our freedom. Yet Locke is careful to point out that it does not, by itself, constitute us as free agents. Locke does not praise deliberation for the sake of deliberation. The point of examining alternative desires and raising uneasiness in our minds is to adjust our will appropriately. We do not simply seek to conform our volitions to our judgments, but to conform our volitions to the good itself. If Locke were simply interested in having us conform our volitions to our judgments, then he would not have been so insistent about pointing out the ways in which custom, habit, and fashion mislead us into making false choices about the good. Indeed he would have no basis for criticizing us for failing to free ourselves from their own parochial interests and biases. If we need only conform our desires to our judgments to be free, it should be sufficient to make sure that our misguided volitions are in line with our misguided judgments. Yet Locke insists that we can be criticized for such failures, and we have a duty to struggle against our native propensity toward error.

Our capacity for judgment is important for Locke as the means by which our will is made to accord with what is best for us. As Yaffe puts it, "Locke invokes the power to suspend the effect of desire in order to deliberate, because he thinks that through such deliberation, we bring it about that our wills are determined by the good." ${ }^{\prime 11}$ Our liberty lies not simply in our ability to make judgments, but rather in our ability to distinguish what is truly best for us from what is counterfeit. Locke writes,

The highest perfection of intellectual nature lies in a careful and constant pursuit of true and solid happiness; so that care of ourselves, that we mistake not imaginary for real happiness, is the necessary foundation of our liberty (II.xxi.51).

By this, I take Locke to be saying that the necessary foundation of our liberty is our ability to care for ourselves by choosing correctly, that is, by choosing in ways that conform to a real rather than

${ }^{11}$ Yaffe, Liberty Worth the Name: Locke on Free Agency., 54. 
imaginary happiness. We pursue a "true and solid happiness" by learning to attune our choices to the good. ${ }^{12}$

This process is not easy, Locke tells us, but it is possible. We are able to attune our will to the good, because we can modify the causal determinates of the will. That is, we can generate a more pressing uneasiness in our mind that surpasses our current uneasiness. In this way we can bring it about that our will conforms to what is truly best. This capacity for assessing and reforming our will is the source of liberty for Locke not simply because it allows us to modify our volitions, but because it allows us to accord our will to our "true and solid happiness;" that is, it allow us to accord our will with the good.

For Locke this process does not limit our freedom. Such determination is "not a restraint or diminution of Freedom" but rather "the very improvement and benefit of it" (II.xxi.48). Locke implies that the more our choices are determined by the good, the closer we approach genuine happiness and true freedom. The less our choices are determined by the good, the closer we draw to "Misery and Slavery" (II.xxi.48). We need only consider God and angels, Locke tells us, to recognize that determination by the good is compatible with true liberty.

If we look upon those superiour Beings above us, who enjoy perfect Happiness, we shall have reason to judge that they are more steadily determined in their choice of Good than we; and yet we have no reason to think they are less happy, or less free, than we are (II.xxi.49).

Although it might be so that the choices of these higher beings are more "steadily determined" by the moral structure of the world than ours are, this does not constitute a lack of freedom at all. These heavenly agents are free even though their choices are determined by, and dependent on, a good external to themselves.

We can see that this type of free agency is very different from the Hobbbesian liberty that Locke embraces at other points in the Essay. Here thoroughgoing free agency involves much more than the expression of our will through action; it involves an almost divine capacity to transcend our immediate desires and then adjust them so that they conform to the good. In fact it seems that divine agency serves as a type of ideal or model for Locke's notion of thoroughgoing free agency. "God himself cannot choose what is not good," Locke writes, "the Freedom of the Almighty hinders not his being determined by what is best" (II.xxi.49). Similarly our true freedom is not limited but perfected in our capacity to align our will with the good. We might not be as "steadily determined" by the good as divine beings, yet we do have a extraordinary capacity to turn our will away from what is not good and align it with that which is most conducive to our long-term happiness. Locke's teaching is clear: as thoroughgoing free agents, we are meant to make use of our ability to suspend and examine our desires in order move closer toward divine perfection, in order to attune our will to what is truly good.

\footnotetext{
${ }^{12}$ For Uday Singh Mehta, however, the Lockean agent is not "authentically free" because it is cut off from its "willful eccentricity." From Mehta's perspective, such individuals "must live in a condition of permanent tutelage." They "surrender" to a set of intellectual practices that shape them into the "complaisant inmates of a Lockean panopticon." (Uday Singh Mehta, The Anxiety of Freedom: Imagination and Individuality in Locke's Political Thought (Ithaca, N.Y: Cornell University Press, 1992). 124-33, 38-41, 61-63, 71-72. While Mehta is right in pointing out the centrality of intellectual restraint in Locke's political project, he does not address Locke's own argument that these contraints are constitutive of freedom. Mehta also seems to overlook the ways in which the internal constraints that Locke advocates facilitate the establishment of a regime in which external constraints are less necessary.

${ }^{13}$ One could further speculate that the differences between the Hobbesian account of free agency and Locke's second account are tied to differing views of divine power. Hobbes follows Luther and Calvin in conceiving of divine sovereignty as unknowable, unlimited, and unrestrained and shares their general approach to the philosophical puzzles surrounding freedom and necessity. Locke, on the other hand, joins many Anglican clergy in his day in embracing the Dutch theologian, Arminius, who rejected the image of God held by orthodox Calvinism. Arminius developed a theory of freedom that shares many of the same concerns that animate Bramhall and Locke. It seems that the assumptions that these thinkers make about divine agency shapes how they conceive of human free agency as well. Divine agency serves as a model for what they imagine human beings capable of being. For the larger religious context of Locke's position, see Victor Nuovo, "Locke's Theology, 1694-1704," in English Philosophy in the Age of Locke, ed. M. A Stewart (Oxford: Clarendon, 2000), M.A. Stewart, "Revealed Religion, the British Debate," in The Cambridge History of Eighteenth-Century Philosophy, ed. Knud Haakonssen (Cambridge Cambridge University Press, 2006).
} 
Yet all of this leaves us with a set of nagging questions. How exactly are we supposed to know what is conducive to our "true and solid happiness"? How are we supposed to align ourselves to the good if we are not exactly sure what it is? One answer that Locke offers is that we should simply follow the natural law. Locke insists at several points in the Essay that it is really not so difficult to discover what the law entails. Every human being should be able to uncover the law of nature (which is the law of God) because it is "knowable by the light of Nature; i.e. without the help of positive Revelation" (I.iii.13). In fact, if we apply ourselves, we can even attain certain knowledge of this law. Locke tells us that we can produce a demonstrable proof, like an Euclidean proof, of our moral obligations if we are careful to proceed logically from abstract, moral concepts to necessary conclusions. By positing moral concepts and then demonstrating what those moral concepts necessarily entail, we can arrive at conclusions that would be acceptable to anyone who could follow the proof. This is what Locke means when he says, "Morality is capable of Demonstration, as well as Mathematicks" (III.xi.16, see also IV.iv.7, IV.iii.18, IV.xii.8).

However Locke does not provide us with a conclusive account of how this method could help us uncover the natural law. It is hard to see how we could determine God's laws through examination of our moral concepts - especially given Locke's rejection of the innateness of moral principles. In order to demonstrate the content of the natural law, we would have to possess all of God's concepts and also be able to reason with them. If we lack the requisite simple ideas - through a lack of experience or reflection - we would be unable to assemble the complex ideas necessary to construct this comprehensive moral law. Without a set of divine experiences of the moral world as well as a divine capacity for reasoning, we would be unable to derive the natural law in its entirety. In short, there are a variety of reasons to think that Locke's demonstrable morality might not reveal the content of God's laws for the vast majority of us. Uncovering the content of the natural law is clearly not be as straightforward as he implies. This might be one of the reasons that Locke himself never accomplished this task.

Of course the fact that Locke does not provide a demonstrative proof of the law of nature does not invalidate his account. It reveals only that demonstrative knowledge of the good is not so easy to attain. One could nonetheless conclude that such knowledge is required for thoroughgoing liberty, making genuine free agency extraordinarily rare, perhaps even an unattainable ideal. Following this line of reasoning, Locke is describing a type of freedom that is only available to those philosophical few who can perfect themselves by perfecting their reasoning. Yet this interpretation seems to run counter to the spirit of the Essay. Locke repeatedly contrasts his approach with the hierarchical and inaccessible arguments of his scholastic contemporaries. His account of free agency is meant to be more accessible; he is clearly and undeniably optimistic about our prospect of recognizing the good. Locke is convinced that most of us, at least sometimes, are able to regulate our desires appropriately. He seems to think that his readers can actually attain the type of free agency that he describes.

This optimism, however, does not seem to be based on his assessment of our natural faculties, but rather on a belief in divine providence. In spite of his claims about demonstrable morality, Locke is hardly sanguine about our epistemological condition. We live in a "fleeting state of Action and Blindness," a "state of Mediocrity," in which certain knowledge is "short and scanty" (IV.xvi.4, IV.xiv.2 IV.xiv.1). Yet even though we often find ourselves fumbling through the darkness of our ignorance, "the Candle, that is set up in us, shines bright enough for all our Purposes" (I.i.5). Locke insists that God provides us with what we need.

Seen in this light, perhaps the type of "knowing" that Locke seems to require for thoroughgoing free agency is different than the certainty promised by moral demonstration. Perhaps this type of knowing has less to do with the content of moral law and more to do with the practices of intellectual selfgovernance. If we are to learn to attune our will to our long-term happiness, we need to develop certain dispositions to the good that will allow us to pursue the good regardless of where the good should happen to be found. To have this type of disposition is not to have a certain demonstrable knowledge of morality or the precepts of natural law, but to have a capacity to make choices in context of profound uncertainty. We have to be ready to make probable judgments about the possible consequences of our volitions and the actions that result from them. Although Locke does not explicitly make this argument, it seems plausible that what is most important to thoroughgoing free agency is the fashioning of a certain type of disposition with regard to probable goods. By suspending our immediate desires and making absent pains and pleasures come alive in our minds, we can raise 
uneasiness concerning what we take to be our "true and solid happiness." In this way we can incrementally adjust our will until it accords with the good.

Thus Locke presents us with two accounts of freedom in the Essay. In one sense we are free when we are able to act according to our volitions without external impediment. Yet in another, more important sense, we are thoroughgoing free agents insofar as we are able to suspend our immediate desires, examine them in light of our long-term happiness, and adjust our will appropriately. The first account of freedom stems from Hobbes and is limited to a type of self-expression through action. The second account is distinct from Hobbes's notion and requires a type of self-transcendence through judgment and contemplation. For Locke, the first account is an accurate description of one aspect of freedom, yet it is ultimately inadequate. We should not accept Hobbesian freedom as thoroughgoing free agency. Locke wants to show his readers that we are free not simply because we are able to act without impediment. We are free because we are able to respond appropriately to what is good and valuable in the world. If we wish to experience ourselves as thoroughgoing free agents, we must strive to conform our choices to the good and govern our conduct according to something beyond our own immediate desires.

\section{Constituting The SelF}

For Locke the capacities that enable us to exercise free agency are the same capacities that constitute us as persons. It is our ability to govern our minds combined with an awareness of that ability that shapes our very identity. Locke distinguishes between the term "Man," which he sees as a biological category involving organized particles of matter, and "Person," which is a very different sort of notion. He locates what he calls the "Person" or the "Self" not in substance, but in consciousness. We are persons not because we have the shape or the substance of persons, but because we are aware of ourselves as persons. This view, he concedes, "will look strange to some Readers." It is worth noting just how strange it looks. In fact, Locke's view of personal identity is much more peculiar than is often recognized. The consequences of his view are in turn more profound.

By locating our identity in consciousness instead of corporeality, Locke rejects our widespread tendency to link who we are to a particular substance. This is odd, since we readily think of persons as complex substances, and personal identity as analogous to substance identity. Aren't we persons for much of the same reasons that the objects around us are things? Both persons and things seem to gain their identity from the substance that gives them form. For example, I assume that I am now the same person who, an hour ago, bumped into the door for the same reason that I assume that the door is still the same one that I bumped into. Both the door and myself appear to be substances that maintain material and spatial continuity with earlier substances.

Yet Locke rejects this commonsensical notion. For him there is no persisting substance, no underlying essence of our identity, that makes up who we are. We are selves insofar as we are conscious of ourselves and of our actions in a world that is distinct from ourselves (II.xxvii.10). We are not selves because we possess substance, but because we possess awareness. "Self is that conscious thinking thing," Locke writes, "which is sensible, or conscious of Pleasure and Pain, capable of Happiness or Misery, and so is concern'd for it self, as far as the consciousness extends" (II.xxvii.17). For Locke consciousness is constitutive. It is our consciousness that sets the boundaries of who we are. The unity or identity of a person is not given prior to consciousness; it exists only in and through our consciousness. We become properly selves only in the process of recognizing and responding to the world as selves. We become aware of the external world as distinct from us, and the actions that we take in response to that world as somehow belonging to us as agents.

Locke explains that it is our awareness of our actions as properly ours that bundles the various events we experience into a unified self. We are conscious of our past actions when we conceive of those actions as something that we performed. A self is properly a self, Locke writes, insofar as it "owns all the Actions of that thing, as its own" (II.xxvii.17). As selves we recognize the actions that we have taken in our lives as our actions. Whether admirable or embarrassing, we accept them as somehow part of who we are. In a similar way, Locke seems to hint that we are also aware of the stimulus of our actions - that is, our volitions - as properly ours. We view our volitions as ours insofar as we conceive of them as arising, at least in part, from our own capacities. Our identity as selves involves a recognition of both our conduct and our will as properly ours. 
Locke believes that this consciousness of voluntary action entails a recognition of responsibility for our choices. A person is by definition someone who is capable of being held accountable for his or her actions. To be accountable for an action is to accept the consequences for the performance of that action. It is to recognize that the action, as well as the will that preceded it, was at least partly in our power. As accountable agents, we recognize that we can be "held to account" for our actions. We recognize that the happiness or misery that our actions bring upon us is in a certain sense fitting. The punishments or rewards that our conduct merits are properly assigned to us as persons. This is why the term can only really be applied to those who are capable of recognizing that they exist within the matrix of laws and obligations. It is "a Forensick term," Locke tells us, "appropriating Actions and their Merit, and so belongs only to intelligent agents capable of a Law, and Happiness and Misery" (II.xxvii.26). We are capable of law, that is, moral law, insofar as we are able recognize that there is some moral standard or ideal that connects our past actions with our present ones. Whether this standard is the elusive natural law or a more accessible measure of probable happiness is ambiguous. Yet Locke clear that the reasonable self is not only able to acknowledge an action as its own, but also to recognize the consequences of that action as its own. It is this awareness of accountability that constitutes us as selves. ${ }^{14}$

Although Locke seems to be primarily concerned with past action, he notes that the consciousness that constitutes us as selves is not only backward-looking but forward-looking as well. We are aware that there is a link between our actions and volitions today and the happiness and misery that we might experience tomorrow. This awareness, Locke tells us, is what links our present actions with our future aspirations and provides the boundary our personal identity. It turns out that the capacities that constitute us as selves are the same capacities that - if appropriately employed - enable us to experience ourselves as thoroughgoing free agents.

Locke tells us that a concern for our future happiness is "an unavoidable concomitant" of our consciousness (II.xxvii.26). To be a self or a person is to be concerned with the happiness and misery that result from our actions. The "great privilege of finite intellectual Beings," Locke tells us, is our capacity to care for ourselves by attending to our "true and solid happiness." For the thoroughgoing free agent as well as for the reasonable self, this involves suspending the demands of our immediate desires and bringing it about that our will accords to real instead of illusory happiness (II.xxi.52). What makes us free agents is our ability to make absent pleasures and pains alive to ourselves in order to influence the present determination of our will. It is through this capacity that we hope to bring about a correspondence between our will and the moral good that structures our experience in the world. To possess such capacities (and to recognize we possess such capacities) is to be properly a self.

In The Protestant Ethic and the Spirit of Capitalism, Max Weber argues that the development of a particular view of the individual, what he calls "personality," made possible the "rationalization" of the state with its calculable legal system and the administration of formal rules. ${ }^{15}$ The "personality" that emerged out of Puritan worldly asceticism was characterized by a

systematic method of rational conduct with the purpose of overcoming the status naturae, to free man from the power of irrational impulses and his dependence on the world and on nature. It attempted to subject man to the supremacy of a purposeful will, to bring his actions under constant self-control with a careful consideration of their ethical consequences. ${ }^{16}$

\footnotetext{
${ }^{14}$ Charles Taylor argues that Locke presents a "punctual self," a "radically subjectivist view of the person" which is characterized by its capacity to "disengage" from the world of things and people. By standing apart from and "objectifying" one's surroundings as well as one's self, the Lockean agent becomes a "self-defining subject." Yet, as I have tried to argue here, the reasonable self that Locke promotes is one that is constantly at work apprehending and conforming to a good that is not self-generated but rather discovered through interaction with a morally marked world. Charles Taylor, Sources of the Self: The Making of the Modern Identity (Cambridge, MA: Harvard University Press, 1989)., 171-2. For a balanced and insightful response to Taylor, see Jerrold E. Seigel, The Idea of the Self : Thought and Experience in Western Europe since the Seventeenth Century (New York: Cambridge University Press, 2005).

${ }^{15}$ Max Weber, The Protestant Ethic and the Spirit of Capitalism (New York: Charles Scribner's Sons, 1993)., 25 .

${ }^{16}$ Ibid., 118-19.
} 
Locke seeks to persuade his readers to embrace the type of cognitive self-discipline that aims at a very similar type of personality. Like the Puritan, Lockean free agents respond to the uncertainty that unsettles those around them by working harder to gain control of themselves. They strive to overcome their dependence on their own desires and the erratic demands of an external world, by transcending themselves and conforming their will to that which is conducive to their long-term happiness.

Thus Locke calls his readers to take up the difficult task of cognitive self-discipline. He tells us that we should engage in this process with an aim toward perfect happiness, yet he warns us that we will always fall short. To be perfectly happy "every uneasiness we feel" must "be perfectly removed: which in the multitude of wants, and desires, we are beset with in this imperfect State, we are not like to be ever freed from in this World" (II.xxi.46). Although we cannot hope to free ourselves from every uneasiness, this type of freedom is not what we should desire anyway. It is our ability to modify and make use of our uneasiness that enables us to move toward our "true and solid happiness." It is through our uneasiness that we can experience the second, more profound type of freedom that is within reach of finite intellectual beings. Thus for Locke our happiness as well as our liberty rests on our willingness to take up this endless struggle to align ourselves with what is most valuable and most important in the world. Only by taking up this hard labor can we hope to transcend our immediate desires and experience ourselves as the kinds of free and reasonable agents capable of self-government.

\section{REFERENCES}

Ayers, Michael. Locke: Epistemology and Ontology. New York: Routledge, 1993.

Bramhall, John. "A Defence of True Liberty." In Hobbes and Bramhall: On Liberty and Necessity, edited by V. C. Chappell. Cambridge: Cambridge University Press, 1999.

Cranston, Maurice. John Locke: A Biography. London: Longman, 1957.

Hobbes, Thomas. Leviathan. Translated by Richard Tuck. Cambridge: Cambridge University Press, 1991.

"Of Liberty and Necessity." In Hobbes and Bramhall: On Liberty and Necessity. Cambridge: Cambridge University Press, 1999.

Locke, John. The Correspondence of John Locke. Edited by E. S. De Beer. Oxford: Clarendon Press, 1980.

Locke, John, and P. H. Nidditch. An Essay Concerning Human Understanding. Oxford: Clarendon Press, 1979.

Marshall, John. John Locke: Resistance, Religion and Responsibility. Cambridge: Cambridge University Press, 1994.

Mehta, Uday Singh. The Anxiety of Freedom: Imagination and Individuality in Locke's Political Thought. Ithaca, N.Y: Cornell University Press, 1992.

Nuovo, Victor. "Locke's Theology, 1694-1704." In English Philosophy in the Age of Locke, edited by M. A Stewart, 183-216. Oxford: Clarendon, 2000.

Seigel, Jerrold E. The Idea of the Self : Thought and Experience in Western Europe since the Seventeenth Century. New York: Cambridge University Press, 2005.

Stewart, M.A. "Revealed Religion, the British Debate." In The Cambridge History of EighteenthCentury Philosophy, edited by Knud Haakonssen, 1:683-709. Cambridge Cambridge University Press, 2006.

Taylor, Charles. Sources of the Self: The Making of the Modern Identity. Cambridge, MA: Harvard University Press, 1989.

Weber, Max. The Protestant Ethic and the Spirit of Capitalism. New York: Charles Scribner's Sons, 1993.

Wood, Neal. The Politics of Locke's Philosophy: A Social Study Of "An Essay Concerning Human Understanding. Berkeley, CA: University of California Press, 1983.

Yaffe, Gideon. Liberty Worth the Name: Locke on Free Agency. Princeton: Princeton University Press, 2000. 